\title{
Sardes: Tarih, Mimarlık ve Şehircilik
}

\section{Sardes: History, Architecture and Urbanization}

\author{
Fikret K. Yegül ${ }^{1}$ (1)
}

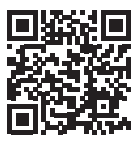

1Sorumlu yazar/Corresponding author: Fikret K. Yegül (Prof. Dr.),

California Üniversitesi, Sanat / Mimarlık Tarihi Bölümü, California, USA

E-posta:yegul@arthistory.ucsb.edu

ORCID ID: 0000-0002-3328-9029

Başvuru/Submitted: 01.11 .2020

Kabul/Accepted: 08.01 .2021

Atıf/Citation: Yegul, F.K. (2020). Sardes: Tarih mimarlık ve şehircilik. Anadolu AraştırmalarıAnatolian Research, 23, 135-158. https://doi.org/10.26650/anar.2020.23.820687

\section{öz}

Antik Sardes Tmolos Dağları́nın (=Bozdağlar) kuzey etekleri ile Hermos (=Gediz Çayı) ovasının güney uzantısı arasında, Paktolos Çayı'nın (=Sart Çayı) vadisinin doğusunda kurulmuştur. Eski doğu-Batı Pers 'Kral Yolu' Sardes'i akropolünün kuzey yamaçlarına yaslanmış "yukarı kent" ve ovaya yayılan "aşağı kent" olarak ikiye ayırıyordu. Arkaik/Lidya devrine tarihlenen taş ve kerpiç kent surları 108 hektarlık bir alanı içine alıyordu. Lidya devri kalıntıları (surlar, tümülüsler, mezarlar, teras duvarları, Paktolos Vadisindeki altın arıtma tesisleri) MÖ 7-6 yüzyıla tarihlenebilir. Kent'de Pers hâkimiyeti MÖ (Buradaki "o" ö harfine teknik bir nedenden dolayı dönüştürülemiyor)547'den Büyük İskender'in MÖ 334'de kenti fethedip, "kurtarması"na kadar sürmüştür. Kentte Iskender sonrası başlayan Helen/Ionia kültürü, özellike MÖ 281'de I. Seleukos'un Sardes'i ve bölgeyi alması ve Sardes'i, imparatorluğunun bati ucunda bir başkent yapmasıyla devam etmiştir. Kentin en görkemli mimari ve dini anıtı Artemis Tapınağının da MÖ 280-260 arası kral I. Antiochos ve kraliçe Stratonike tarafından yapıldığını sanıyoruz. Hellenistik devirde sadece cella'sı bitirilen tapınak, ancak Hadrianus'un Sardes'i MS 123/124'de ziyareti sonucu kazanılan İmparatorluk kültünü içerisine alarak devasa bir lonik pseudodipteros halinde getirilmiş, fakat bitirilememiştir. Hellenistik devirde büyük bir tiyatro; Roma devrinde de onunla bir grup yapan stadyum ve sütunlu bir teras ortasında yükselen bir İmparatorluk kültü tapınağı ve ovada mermer caddenin üstünde devasa bir hamam-gymnasion yapılmıştır.

Anahtar Kelimeler: Sardes, Lidya, Anadolu, Şehircilik, Seleukos İmparatorluğu

\section{ABSTRACT}

Sardis is located on the northern foothills of Tmolos Mountains in western Anatolia. It was the capital of the Lydian Kingdom until its defeat by the Persians in 547 BCE. The city became the western capital of the Seleucid Empire in 280 BCE. The Lydian city featured massive fortifications with terraced structures. Hellenistic and Roman Sardis followed the organic planning principles of its predecessor, never adopting the grid plan. The foremost monument of the ancient city is the Temple of Artemis, the largest pseudodipteros of the ancient world, started under the Seleucids (ca. 280-260 BCE) and completed under Hadrian.

Keywords: Sardis, Lydia, Anatolia, Urban Planning, Seleukids 


\section{EXTENDED ABSTRACT}

The ancient city is located between the Tmolos Mountains and the Hermus Plain east of the Pactolus River valley. A massive stone and mudbrick fortification wall of the late Lydian period, some 18-20 m thick, extends down from the slopes of the acropolis, one of the northern spurs of the Tmolos, towards the plain enclosing an area of 108 hectares. According to Herodotus, Herakles was the legendary founder of the city and the Heraklid dynasty going back to the late Bronze Age (Herodotus I.7). Croesus, the last Lydian king was defeated by the Persian King Cyrus in 547 BCE. The Persian rule at Sardis, lasted two centuries until the city was "liberated" by Alexander the Great in 334 BCE (Arrianus, Anabasis, 1.17.3-6). The city and the region were made a part of the Seleucid Empire when Seleukos I Nikator defeated Lysimachus in the Battle of Kourepedion in 281 BCE.

Upon Seleukos' death, his son Antiochus I and his queen Stratonike settled in Sardis it a regional western capital of the Seleukid Kingdom until its defeat in the Battle of Magnesia in $189 \mathrm{BCE}$ by the combined forces of Pergamon and Rome. We believe that the construction of the temple in the Artemis sanctuary commenced soon after the conquest of Sardis by Seleukos, possibly under the leadership of queen Stratonike who lived in Sardis.

City planning of Sardis never followed popular grid-iron models; rather, topographical opportunities seem to have dictated the shape of the city producing a more flexible and organic arrangement. A major east-west road marking the course of the Persian Royal Road connecting the coast with the inland divided the plain and the northern foothills of the acropolis - in effect, creating an "upper city" and a "lower city." The upper city was probably the preferred neighborhood of the wealthier classes.

Lydian era terrace walls of fine limestone preserved up to 6-7 $\mathrm{m}$ high and possibly connected to each other by stairs, ramps, and tunnels, were uncovered at several locations on acropolis slopes. Massive terraces probably supported large residences or palaces, one being possibly the 'Lydian Palace' (mentioned in Pliny and Vitruvius as Croesus' palace later turned into a gerousia or senior's meeting place: Pliny, NH 35, 172; Vitruvius, 2.8.910). A major addition of the Hellenistic period was the theater, enlarged with a two-story columnar skene frons during the Roman period; the stadium that extends west beyond the stage building was added around the same time. Inscriptions and ancient sources mention an agora and stoa, gymnasium, and a mint from Lydian and Hellenistic periods, but their locations are unknown. There was considerable settlement outside the city walls at all periods (the latter removed during the Persian period), especially along the Pactolus valley, including a gold refining workshop/sanctuary presided over by a Lydian altar of Kybebe from the sixth century BCE. 
The Roman era was ushered in by the devastating earthquake of AD 17 which elicited fiscal relief from Rome. Many Roman era buildings are characterized by large, vaulted structures typical of Roman construction, such as the stadium. Notable among them is a midfirst century CE Imperial cult temple (Vadi-B temple, an octastyle Corinthian pseudodipteros) elevated on a vast rectangular colonnaded enclosure approached by an axial, monumental staircase; an early second century bath-gymnasium complex of the symmetrical imperial type featuring a ceremonial hall displaying a colonnaded aediculae in two stories; an eastwest marble colonnaded avenue which received a monumental city gate in late Roman times.

For monumentality and cultural importance, the most outstanding monument of GrecoRoman Sardis was the Temple of Artemis. The cult of Artemis was introduced to the city from Ephesus in the late sixth century or so, when a monumental altar was built in the sanctuary against the backdrop of the acropolis. The temple, started ca. 280-270 BCE, might have been intended to be a dipteros like the archaic dipteroi of Ionia. Only the long allmarble cella, facing west, was finished. Work resumed to complete the temple as an Ionic peripteros after the visit of Sardis by Hadrian and Sabina in AD 123/24, an honor which culminated by the granting of the city its second neokoros privilege. Besides starting the construction of the monumental peripteros the cella was divided into two, Artemis retaining her western chamber while the cult of the emperors (with their colossal portrait icons) moved into the new eastern one. The east side seems to have been finished with all its columns, but ironically, the western, Artemis side was never completed. With a pteroma of unequal with around the cella, and spacious and open six-column pronaos porches at the ends, the plan of the Artemis temple at Sardis does not follow the standard pseudodipteral plan of Hermogenes at Magnesia or its Hellenistic and Roman followers. 


\section{Giriş}

Sardes Amerikan Kazıları'nın ilk başkanı Howard Crosby Butler, 1909 yılında yazdı̆̆ı bir raporda, Sardes'in Doğu ve Batı arasında bir köprü olduğunu ve özellikle, AnadoluIonia ve Grek uygarlıklarının ilişkilerini açıklığa kavuşturabilecek bir anahtar olabileceğini vurguluyordu. "Sardes ilk altın paranın basıldığı Lidya imparatorluğunun altın yüklü Paktolos ırmağı üstündeki Grek-Pers savaşları boyunca Anadolu'da idare merkezi olan Akhamenid satraplı̆̆g, Büyük İskender'in Pers boyunduruğundan kurtardığ1 ilk kent, Roma idaresi altında büyük ve nüfuzlu bir ticaret merkezi ve erken Hristiyanlık döneminde 'Asya'nın Yedi Kilisesi'nden' biridir,” diyordu (Yegül, 2010a, 61). ( Resim 1)

İlginçtir ki, Butler'dan 30 yıl önce, 1879'da Heinrich Schliemann da “Sardes sabırsızlıkla kazma ve küreğimi alıp gelmemi bekliyor ... Mikene ve Troia’ dan sonra ilk kazacağım yerdir ...” diyerek Kroisos'un 'Altın Kentinin' önemini dile getiriyordu (Yegül, 2010a, 61-63).

Schliemann -belki de bu bakımdan şanslıyız - Sardes’te hiçbir zaman kazma sallamadı. Sardes'te ilk planlı kazılar Princeton Üniversitesi profesörlerinden Howard Crosby Butler başkanlığında 'American Society for the Excavation of Sardis' (Sardes Kazıları Amerikan Heyeti) adlı özel bir dernek tarafindan 1910-1914 arasında yapıldı. Bu dört yılda Artemis tapınağının tümü ve çevresindeki kutsal alan; Paktolos (Sard) çayının batı yamacında yer alan büyük Lidya nekropolisi; kentin $11 \mathrm{~km}$ kuzeyinde Hermos (Gediz) ovasına yayılan Lidya ve Pers kralları ile asilzadelerinin tümülüs mezarlarının bir kısmı (Bin Tepeler) ve Paktolos ırmağının doğu yakasındaki bir vadide gizlenen piramid biçiminde taş anıtsal bir mezar ('piramid mezar,' yaklaşık MÖ 550-500) ortaya çıkarıldı. Sonuçlar dokuz cilt halinde yayınlandı (Hanfmann \& Waldbaum 1975, 1-3). Birinci Dünya Harbi ve arkasından TürkYunan Harbi (1918-1922) dolayısıyla durdurulan kazılar bir daha başlatılamamıştır. Bunun arkasında yatan en büyük neden ise Sardes Kazı heyeti ve başkanının 1922'de Yunan işgali altında gerçekleşen son sezon çalışması ardından 58 sandık eski eser ve 30 altın Kroisos sikkesinin kanun dışı yollarla, Yunan işgal kuvvetlerinin yardımıyla Amerika'ya (New York, Metropolitan Sanat Müzesine) kaçırması olmuştur. Eserlerin büyük çoğunluğu (sikkelerin 26's1) Türk ve Amerikan heyetlerinin, özellikle İstanbul Arkeoloji Müzesi Müdürü Halil Edhem'in uğraşlarıyla başardıkları anlaşma sonucu 1926 yılında Türkiye'ye getirilmiştir. Birinci Dünya harbi sırasında Osmanlı-Türk karşıtı bazı çalışmalara adı karışan başkan Butler, 1922'de Paris’te olmuştur (Yegül, 2010a, 57-100; Yegül, 2013, 711-26).

İkinci dönem Sardes kazıları ve yayınları ise Harvard ve Cornell Üniversiteleri gözetiminde, Harvard'dan Profesör George M. A. Hanfmann başkanlığında 1958'te başlayarak, 1976 yılına kadar sürdürüldü. 1977'den itibaren 2008 yılına kadar kazılar Profesör Crawford Greenewalt Jr. başkanlığında gerçekleşti. 2008'den beri ise Profesör Nicholas Cahill başkanlığında devam ediyor (bkz. https://www.sardisexpedition.org). Buna 
rağmen, surlar içinde 108 hektar (çevresiyle yaklaşık 200 hektar) yer kaplayan antik kentin ancak küçük bir kısmı ortaya çıkarılabilmiştir. Eski çağlardan beri devamlı yerleşim ve tarım alanı olan antik Sardes'in (günümüzde Sart Mahmut ve Sart Mustafa köyleri, eski İzmirAnkara karayolunun üzerinde, Salihli’nin $10 \mathrm{~km}$ batısında) büyük bir bölümü erozyon, tarım faaliyetleri ve yapı malzemesinin, özellikle mermer bloklarının, başka amaçlarla kullanılması sonucu yok olmuştur.

\section{Sardes Antik Kenti’nin Konumu ve Kısa Tarihi}

Antik Sardes kenti Tmolos (Bozdağ) dağlarının kuzey uzantısı olan yüksek tepeler ile, Hermos (Gediz) ovasının arasında; Hermos nehri ile birleşen Paktolos çayının hemen doğusunda yer alır. Kent, sarp yamaçları ovadan yükselen akropolisin kuzey tepelerinin eteklerinde ve hemen tepelerin uzantısı ovada kurulmuştur [Resim 2, 3]. Kent ve bölge, tarıma elverişliliği, Tmolos eteklerindeki ormanları ve kentin yapı sanayisine hizmet veren mermer ocakları ve Paktolos sularının taşıdığı, Lidya'nın ve kral Kroisos’un ünlü zenginliğini sağlayan altını ile Anadolu'nun önemli Eskiçağ merkezlerindendi.

Geç Lidya devrine (MÖ 7-6 yüzyıl) tarihlenen taş ve kerpiç kent duvarları akropolisin keskin yamaçlarından aşağılara inerek 108-110 hektarlık bir alanı içerisine alıyordu. Surların kuzeybatısındaki bir bölüm ve 'batı sur kapısı' ortaya çıkarılmıştır. 10-18 m genişlikte (tabanda bazen glacis denilen toprak-çakıl geniş koruma rampasıyla 20-30 m) ve 10-13 m yükseklikte olduğu saptanan Sardes surlarının ünlü Mezopotamya ve Yakın Doğu kentlerinin surlarından aşağı kalmadığı belirlenmiştir [Resim 4]. Sardes Lidya döneminden Bizans'a kadar hep bu 3-3.5 km çevre uzunluğu olan surların içinde kalmışsa da değişik zamanlarda Paktolos vadisi ve ovanın doğuya uzantısında, sur dışı yerleşimlere de taşmıştır (konutlar, pazar ve sanayi merkezleri, işlikler ve büyüklü küçüklü kutsal alanlar gibi). Uzun Lidya duvarının ancak çok küçük bir kısmı tespit edilmiştir. Ancak, eski surların güzergâhını izleyen geç Roma ve Bizans surları bize antik kentin sınırlarını gösterir. Büyük bir olasılıkla, bu duvarların kapladığı geniş alanın tümü kentsel bir doku ile kaplanmamıştı. Bugün antik kentin içinden batı-doğu yönünde geçen eski İzmir-Ankara yolunun, Pers devrinin (MÖ 6-4 yüzyıl) ünlü Kral Yolu'nu izlediği bilinmektedir. Bu ana güzergâh, Roma döneminde kenti kuzeygüney (ova-dağ) bölümlerine ayıran mermer döşeli sütunlu bir cadde olarak geliştirilmiştir (Cahill, 2019a, 11-18; Cahill, 2010, 75-86; Ratté, 2011, 108-112). Sardes'in Lidya Krallı̆̆1 döneminde genellikle kerpiç ve moloz taş yapılı bir görünüm verdiği biliniyorsa da uygarlığı, zenginliği ve insanlarının bilgeliği ile de öne çıkıyordu. Bununla birlikte gösterişe, lükse ve biraz da ahlak dışı yaşama düşkünlüğü ile tanınmış, sofistike bir kent olarak biliniyordu. MÖ 7. yüzyıl sonlarında yazan şair Alkman, Sardeslileri şöyle betimliyordu: "Sen öyle aptal, kaba ve kendini bilmez biri değil, Sardes gibi yüksek bir yerin adamısın!" (Alkman 16, 24B, 13D; ayrıca, Sardes ve Sardesliler hakkında: Athenaeus, Deipnosophistae, 2.48; 2.53; 2.515d-f; 15.690b-d; Herodotos, 1.94). 
Herodotos'a göre, Sardes ve Sardeslilerin ataları Herakles’ten gelen ve tarihi Geç Tunç Çağına dayanan (yaklaşık MÖ 1300-1200) Heraklidler hanedanıdır. Bu hanedanın son kralı Kandaules garip bir arzu ile kraliçesinin güzelliğini muhafız alayının komutanı Gyges'e gizlice seyrettirince, bu işin farkına varan kraliçe, Gyges'e eğer yaşamak isterse kocasını öldürüp kendisi ile evlenmesini ve krallık tahtına oturmasını emreder [Resim 5]. Böylece Sardes'te MÖ 680'de Gyges'le Mermnad hanedanı dönemi başlamış olur ( Herodotus, 1-12). Bu hanedan özellikle son kralı Kroisos zamanında zenginliği ve kuvvetiyle ünlenmiştir. Paktolos sularından altın arıtan kral, birçok İon ve Grek toplumuna, Ephesos Artemis Tapınağına ve hatta Delphoi'daki Apollon Kutsal Alanına cömert bağışları ile tanınır. Kuvvetine fazla güvenen Kroisos akılsızca Pers krallığına savaş açmasına ve hem kendisinin hem de ülkesinin Pers kralı Kyros tarafından MÖ 546'da yenilgiye uğramasına, bu şekilde Perslerin Anadolu toprakları hakimiyetleri altına almasına neden olmuştur. Bağımsızlığını kaybeden Sardes, Perslerin batıdaki bir ileri karakolu, bir satraplık merkezi haline dönüşmüştür. Sardes’in geçmişindeki bu safhalar bir dereceye kadar arkeoloji tarafından doğrulanmıştır. Kentin bazı bölgelerinde ve 11 km kuzeyindeki Gyges (Marmara) Gölü güney kıyılarında, MÖ 3. binden başlayarak, Tunç Çağı, Protogeometrik, Geometrik ve Miken seramikleri bulunmuştur (Cahill, 2019a, 18-23; Hanfmann, 1983, 13-25) .

Pers döneminde (MÖ 547-334) yönetim askerî bir merkez olan akropoliste toplanarak, Sardes bir "kale kenti”, Pers imparatorluğunun batıdaki topraklarını gözlemleyen bir garnizon olmuştur. Her ne kadar bugün akropoliste Bizans devri surları ve kalesi dışında fazla yapı kalmamışsa da burada Lidya kral ve üst düzey yöneticilerinin bir kale-sarayı olabileceğini ve böyle bir güvenli saray grubunun Pers satrapı ve askerî personeli tarafından da kullanıldığını sanıyoruz. Böyle bir zirve sarayının, ayrıca tüneller ve rampalarla akropolisin yamaçlarındaki teraslar üzerine kurulmuş kent-sarayları ile birleşmesi de olasıdır (bkz., aşağıda). Bunun dışında, kent dışı dinî merkezler ve kentin eski tanrılarını onurlandıran kutsal alanlar (örneğin, Kuvava/Kybele, Artemis, Zeus Lydios, Zeus Polieus, Dionysios) önemini yitirmemişdir (Greenewalt, Jr. 2010, 233-46; Hanfmann 1983, 73-74, 110-13). Toplumların yaşamlarına etkisi olan, krallar, ordular, savaşlar gibi büyük olayların etkisinde kalarak, görece daha yavaş değişen geleneklerin yönlendirdiği halkın günlük yaşantısına pek dikkat edilmemektedir. Sardes kenti ve civarında bulunan seramik gruplarına bakarak, Pers idaresi altındaki Lidya halkının da Lidya sofra takımlarını ve yemek geleneklerini kaybetmeden, bazı yeni Pers/ Akhamenid sofra ve içki takımlarının kullanımından, Pers mutfak kültürünü kabul etmeye başladıkları (iki geleneği birleştirdikleri) anlaşılmaktadır. MÖ 5. yüzyılda toplumsal hayatta kendini hissettirmeye başlayan söz konusu küçük çaplı İran etkileri ve Lidya-İran kültür sentezi MÖ 4. yüzyılın sonunda ve 3. yüzyılın başlarında Hellenistik seramiğin devreye girmesi ve kozmopolit geniş Hellen kültürünün kabulü ile kaybolmuştur (Hanfmann, 1983, 83-87; Mierse, 1983, 100-106). 
Nikomedialı (İzmit) Arrianos Büyük İskender'in seferlerini konu eden Anabasis eserinde Makedonyalı generalin MÖ 334'te Sardes'i güç kullanmadan ele geçirerek, iki yüzyıllık Pers boyunduruğundan kurtardığını yazar. Arrianos'a göre, İskender teslim olan İranlı kale komutanını ve kent anahtarını teslim etmeye gelen Lidya yaşlılarını akropoliste kabul ettikten sonra, aşağılara, ayaklarının altında gibi görünen Artemis kutsal alanına ve sunağına, sonra uzaklarda Hermos ovasında uzanan Lidya topraklarına bakarak, artık Sardeslilerin özgür olduklarını ve atalarından kalma Lidya geleneklerini yeniden, istedikleri gibi, canlandırabileceklerini söyler (Arrianos, Anabasis 1.17.3-6).

Büyük İskender'in akropolis zirvesindeki heyecan verici söylevi ile MÖ 281'de Sardes ve batı Anadolu'nun Seleukos hakimiyeti altına girmesi arasında geçen yarım yüzyıllık “özgürlük” döneminin Sardes’i nasıl etkilediğini, kentin fizikî, idarî ve kültürel gelişiminde nasıl bir rol oynadığını bilinmemektedir. Bazı tarihçilere göre MÖ 323 'te İskender'in ölümüyle generalleri (diadokhoi) arasında başlayan taht kavgasının neden olduğu savaş ve karışıklık dönemi Sardes’i de etkilemiş olabilir, diğerlerine göre ise (bu fikre ben de katılıyorum) Sardes geri planda kaldığı için bu dönem nispeten sessiz geçmiştir. Görüşümüze göre, bu belirsiz İskender sonrası "geçiş döneminde," zaten hiçbir zaman tam olarak kaybolmamış olan Lidya kültürü yeni beliren Grek kültürü ve sanatı ile yavaş bir tempo ile kaynaşmaya başlamıştır. Sardes arkeolojisinde bu dönemi açığa çıkaracak net veriler ve mimarî projeler ortaya çıkmasa bile, bu dönemde kent merkezindeki boşlukların artımlı bir şekilde dolduğu ve değişikliğin küçük adımlarla yürüdüğü, 1lımlı bir varsayım olarak kabul görebilir.

İskenderin ölümünden hemen sonraki bu dönemde Sardes için belki en önemli jeopolitik olay, MÖ 320-308 yılları arasında kentin, ülkesinden kaçan Makedonyalı prenses, Epiros kraliçesi Olympias'ın kızı, Büyük İskender'in kız kardeşi II. Kleopatra'ya oniki yıl evsahipliği yapmasıdır. Aslında Sardes'te bir nevi sürgün hayatı yaşayan Kleopatra MÖ 308'de, Mısır hâkimi Ptolemaios'la olası evliliğini engellemek için Antigonos Monophthalmos tarafından öldürtülmüştü. “Tek gözlü” Antigonos yaptığı kalleşliği ört-bas etmek için (ve sonuçlarından korktuğu için) prensese görkemli bir cenaze töreni düzenlemişti. Ancak bu anıt mezarın nerede olduğunu bilmiyoruz. Aşağıda göreceğimiz gibi, Sardes’te bir dönem yaşayan ve ölen tek Makedonyalı prenses Kleopatra değildir (Yegül, 2020b, 9-33; Yegül, 2020a, 160-61).

Sardes'in Hellenistik döneme tam olarak adım attığını vurgulayan bir tarih ve olay vermek gerekirse, I. Seleukos (Nikator)'un doğudan gelip, MÖ 281'de, o zaman Batı Anadolu ve Lidya'yı elinde tutan İskender generallerinden Lysimakhos'u, Kourupedion (Manisa yakınlarında) savaşında yenilgiye uğratması, kenti ve batı Anadolu'nun büyük bir kısmını hâkimiyeti altına almasından söz edilebilir. Seleukos bu büyük zaferinden birkaç ay sonra öldürülünce, bu topraklar oğlu I. Antiokhos ve kraliçesi Stratonike’ye kalmıştır. Lidya imparatorluğunun başkenti, altın kent Sardes de yeni kral ve kraliçenin yerleştikleri Seleukos krallığının batı merkezi olmuştur. Sardes'in, Anadolu’yu doğudaki kuvvet merkezlerine 
bağlayan Kral Yolu'nun batıdaki son durağı olması bu seçimin jeopolitik mantığının tartışılmazlığını kanıtlamaktadır. Didyma'da bulunan ve MÖ 3. yüzyılın ortalarına tarihlenen bir yazıtta, Sardes Artemis Kutsal Alanının Seleukos Krallık Arşivlerinin saklandığı yer olarak belirlenmesi, Sardes' in bölgesel bir 'başkent' olduğuna ve o tarihte kutsal alanda bir tapınağın var olduğuna işaret etmektedir (I. Didyma 492A-C, 44-45 = OGIS 225). Bu tapınağın inşasına I. Antiokhos ve Stratonike'nin Sardes'te oturdukları yıllarda (ve özellikle Stratonike'nin bir adağı ve bağışı olarak) başlanmış olacağına inanıyoruz (bkz., aşağıda) (Wiegand \& Rehm 1958; I Didyma, 492A-C, 44-45=OGIS 225; Yegül, 2020a, xxi-xxii, 10-12).

Sardes Seleukoslar devrinde (yaklaşık MÖ 281-188) kentsel gelişmeler göstermiş, kültür, sanat ve toplum idaresinde gerçek bir Grek polisi karakteri kazanmıştır. Bu gelişmelere bakarak, kentin polis ayrıcalığını MÖ 3. yüzyılın ortalarında veya sonlarına doğru almış olacağını sanıyoruz. Bu dönemde kentin politik yaşamında görülen en büyük kriz MÖ 220'de Anadolu'ya Seleukos kralı III. Antiokhos tarafından satrap olarak gönderilen ancak bu bölgede idareyi eline geçirip Sardes’te krallığını ilan eden Akhaeos'un MÖ 213'de amcası III. Antiokhos tarafından Sardes akropolisinde iki yıl kuşatılmasından sonra yenilgiye uğratılmasıdır (Polybios, 7.18. 9). Kaynaklar bu savaşta kentin ağır hasara uğradığını bildiriyorlarsa da yeni araştırmalar, hasarın biraz abartılmış olduğunu göstermektedir. Antiokhos'un Sardeslilere yazdığı, sonradan kentin Kybele Metroon'unun anta duvarına yazdırılmış mektupta, Akhaeos'u kabul edip kendine isyan eden Sardeslileri “bağışladığını" bildirilmiştir (bkz., aşağıda) (Cahill, 2019b, 91-95; Yegül, 2020a, 207, n. 246) .

Antiokhos'un MÖ 189'da Magnesia savaşında ortak Roma ve Pergamon güçlerine yenilmesi ve bir yıl sonra yapılan Apamea anlaşması, Sardes'te ve batı Anadolu'da bir yüzyıllık varlık gösteren Seleukos krallığının sona erdiğini, Sardes'in Pergamon idaresi altına girdiğini işaret etmektedir. Yarım yüzyıl sonra MÖ 133’te III. Attalos'un Pergamon krallığınının tüm topraklarını Batı'da gelişen Roma'ya devretmesi ile, Asya eyaletinin diğer kentleri gibi, Sardes de Anadolu'nun zaman içinde gelişen kozmopolit Roma düzeninin parçası olmuştur. Romalı şair Catullus’un “Uçalım Asya'nın aydınlık kentlerine!” (Ad Claras Asia Volemus Urbes, 46.6) diyerek belirttiği Anadolu'nun güzel kentlerinin en güzellerinden biri olarak tam bağımsızlığını olmasa bile, saygınlığını ve değerini korumuştur (Catullus, Carmina 46.6).

\section{Mimari ve Şehircilik}

Sardes'in nasıl bir plana sahip olduğunu tam olarak bilmiyoruz; ancak hiçbir dönemde 1zgara bir plan kullanılmadığg anlaşılmaktadır [Resim 2, 3]. Akropolisin kuzey yamaçlarından aşağılara inen duvarlar içindeki bölgede, tepe ve vadilere uzanan teraslar uzerinde yükselen küçük veya büyük yapı grupları ile bir "yukarı kent” ve aşağılarda Hermos ovasına kısmen yayılan bir "aşağı kent” vardı. Planlama, araziye uyan, yer yer değişken, bugün 'organik' 
diyebileceğimiz bir görünüm sergiliyor olmalıydı. Havadar ve manzaralı yukarı kentin daha zengin ve üst düzey sınıflarının oturduğu ve bu şekilde sosyal ayrımı vurguladığını sanıyoruz. Yine de Hellenistik-Roma tiyatrosunun caveasının altında da açı̆̆a çıkarılan Lidya evleri kentin akropolis tepelerinin sadece soylular için değil, normal Lidya meskenleri için de tercih edilen alanlar olduğuna işaret ediyor. Her dönemde, bu iki kısmın -yukarı ve aşağı kent- doğu-batı doğrultusunda bir ana yol veya Roma döneminde, mermer döşeli, sütunlu, üzerinde dükkânlar bulunan bir ana cadde ile ayrıldığını söyleyebiliriz.

\section{Lidya ve Pers İdaresi Devri}

Lidya Sardes'inden günümüze ulaşan mimari eser sayısı azdır ve kentin şeklini aydınlatacak büyük gruplar halinde değildir. Anıtsal mimari olarak kentin 11 km kuzeyindeki ünlü "kral tümülüsleri” (Bin Tepeler) ve bu tümülüslerin içinde çoğu araştırılmış (ve hemen hemen tamamı eski devirlerde yağmalanmış) olan küçüklü büyüklü kesme kireçtaşı, nadiren mermer mezar odaları, Lidya taş işçiliğinin en ince ve ustalıklı eserleridir. Yüz kadar olduğu sanılan bu kral ve aristokrat tümülüslerinin yapımı ve kullanımı Pers dönemini de kapsar. Tümülüslerin en büyüğü, Kral Alyattes Tümülüsü (355 m çapı ve 60 m yükseklik) ile Mısır piramitlerini andırır. Bu tümülüsün mezar odasına 1853 yılında girilmiştir. Bu tümülüsten biraz daha küçük Karnıyarık Tepe'de (220 m çap, 50 m yükseklik) yakın zamanda mezar odası arama çalışmaları henüz sonuç vermemiştir. Ayrıca, Paktolos'un doğusuna açılan küçük vadilerin birinde, Arkaik/Pers devrinden (yaklaşık MÖ 6. yüzyılın ikinci yarısı) alt yapısı basamaklı bir piramit şeklinde, ince taş yapılı, özellikle İran'daki Pazargad anıt mezarlarının işçiliğine benzeyen, belki Pers ileri gelenlerinden birine ait bir "piramit mezar" bulunmuştur (Hanfmann, 1983, 55-58, 42; Ratté, 2011, 69-86, 94-99).

Akropolisin kuzey yamaçlarında Lidya dönemi ince taş isçiliği sergileyen en görkemli teras duvarlarının akropolisin kuzeye bakan zirvesine yakın, birbirlerine basamaklarla bağlı, 7 m yüksekliğe erişen bir teras grubunun, Lidya krallık sarayına ait olabileceği kuvvetli bir olasılıktır [Resim 2, 3, 6, 7]. Daha aşağıda, yine köşeli bir Lidya terası ve onun 150-200 m doğusunda "Field 49" denilen ve daha geniş bir alana yayılan çeşitli terasların üzerinde yükselen, elit bir yerleşim olduğu düşünülebilir. Bu duvarların taşıdıkları orijinal yapılardan geriye birşey kalmamıştır. Bu teraslı yapıları birbirine bağlayan yollar, rampalar, merdivenler ve Sardes'in övgüyle bahsedilen ünlü parkları ve bahçeleri olmalıdır (Pedley, 1972, 80-81; Diodoros, 14.80.2; Cicero, de Senectute, 59). Ayrıca, bu büyük dokunun içine serpiştirilmiş mesken grupları da olabilirdi. Sardes'in bu peyzaj karakterli, dramatik kent görünümünün Hellenistik ve Roma dönemlerinde de devam ettiği kuşkusuzdur (Ratté, 2011, 3-16; Cahill, 2019a, 11-36).

MÖ 5. yüzyılda yaşayan tarihçi Herodotos MÖ 499'da kenti ateşe veren İonia isyanından bahsederken Sardes'in kerpiç duvarlı ve saz damlı evlerinin kolayca yandığını aktarmıştır 
(Herodotos, 5.101). Uzun yıllar yapılan kazılar birçok Lidya konutunun gerçekten moloz ve kerpiç duvarlı, ahşap ve saz çatıl1, toprak zeminli düzensiz bir avlu etrafında tek veya birkaç odadan ibaret, bugün basit Anadolu köylerinde olduğu gibi tarımsal yerleşimler olduğunu göstermektedir. Fakat bu basit tipin dışında, zengin evlerinin ve bazı kamu yapıların çatı elemanlarının renkli desenli, mitolojik konuları betimleyen pişmiş toprak plakalarla süslenmiş olduğunu biliyoruz. Herodotos, yukarıda bahsedilen bölümde Paktolos çayınınLidya agorasının içinden geçtiğini yazıyor, fakat Paktolos vadisinde yapılan çeşitli kazı ve araştırmalarda böyle bir agora bulunmamıştır. Lidya agorasının surların içinde, Paktolos'un 500-600 m doğusundaki düzlük alanda olduğu sanılmaktadır. Paktolos vadisinde basit yerleşim yerleri, kutsal alanlar, işlikler ve Paktolos çayının sularından elde edilen altının eritme ve arıtma sanayi bölgeleri olduğunu bilinmektedir. Bu şehir dişı yerleşimler, özellikle mesken grupları, Pers istilası sonucu kent içinin boşalmasından sonra gelişmişlerdir.

Lidya kentinde yerini ve mimari özelliklerini bilmediğimiz fakat yazıtlarda ve eskiçağ kaynaklarında bir Lidya darphanesinden ve Kral Gyges zamanından bir arşiv binasından bahsedilir. Ayrıca Plinius Kroisos zamanından kalan bir sarayın kent senatosunun toplantı yeri olduğunu belirtmiştir (Plinius, NH 35.172). Vitruvius da bu sarayın bir gerousiaya ('yaşl1lar idare meclisi') dönüştügünü bildirir (Vitruvius, De architettura 2.8.9-10; Ayrica, Sardes'in kentleşme dönemleri için bir özet olarak, Hanfmann \& Waldbaum 1975, 28-34. ).

\section{Hellenistik Sardes}

Hellenistik dönemde Lidya kentinin dokusu aynı kalmakla beraber, kentteki "boşlukların doldurulmasının" ve Pers devrinde bakımsız kalan binaların yenilenmesinin ve canlanmasının en önde giden uğraşılardan olduğunu sanıyoruz [Resim 2]. Bu arada önemli bir uygulama da Perslerin kapattıkları batı sur kapısının ve caddenin açılıp, doğu-batı yolunun yenilenmesi olmuştur. Bu dönemde, Lidya surları büyük ölçüde ortadan kaldırılmıştır [Resim 4]. Kutsal alanlar ve tapınakları saymazsak, Pers idaresi zamanında görülen kent dışındaki yerleşimler (Paktolos vadisi gibi) bir dereceye kadar terk edilmiş, yerleşim tekrar şehir merkezine dönmüştü. Yukarı kentin teraslı yapıları, sarayları ve bahçeleri tekrar yapılanmış, canlanmıştı. Bu saraylar, belki de Kleopatra'nın ve sonra Kraliçe Stratonike'nin yaşadığı hem birbiriyle hem de akropolisle bağlantılı olan saraylardı [Resim 6, 7]. En önemlisi, Sardes İskender ile başlayıp, Seleukoslarla devam eden dönemde, tam anlamıyla Grek/İonia kültür ve sanatına açılmış ve tarihinde ilk defa Lidya/Anadolu kenti görünümünü yitirerek, bir Hellen/Anadolu kenti olmuştu (Hanfmann, 1983, 113-19; Ratté, 2008, 125-35; Cahill, 2019a, 28-36; Kosmin, 2019, 75-90; Stinson, 2019, 139-42; Berlin, 2019, 50-67).

Sardes'in Grek kültürüne açılmasının en göze çarpan örneği akropolisin kuzeydoğu yamaçlarına yaslanan tiyatrosudur (yaklaşık MÖ 3. yüzyılın ortaları?) [Resim 2, 3]. Bu Hellenistik tiyatro sonradan büyütülmüş ve iki katlı ve sütunlu bir sahne binası ile tipik bir 
Roma tiyatrosuna dönüştürülmüştür. Ayrıca, sahne binasının arkasından batıya uzanan bir stadion yapılmış, böylece Roma döneminde bazı Anadolu kentlerinde gördüğümuz tiyatro ve stadion ilişkisi mimari bir bütünlük yaratmıştır (örneğin Aizanoi, Nysa, Perge, Selge). Tonozlu, 'Roma betonu' (opus caementicium) yap1s1 ile tipik bir Roma eseri olan stadion, geçmişi Hellenistik döneme uzanan daha basit bir stadionun devamı olabilir. Tiyatro ve stadion grubunun batıya uzanan düzlüğünde adlarına ancak yazıtlarda rastladığımız ve belki de bir Lidya agora/pazar yerinin uzantısı olan, Grek tipi bir agora-stoa ve bir gymnasion bulunması söz konusu olabilir.

Tiyatro caveasının altında yapılan kazılarda bulunan MÖ 3. yüzyılın başlarına tarihlenen bir grup terracotta (pişmiş toprak) Kybele heykelciği, tiyatrodan daha önce burada kent tanrıçası Kuvava/Kybele'ye ait bir kutsal yapının (sunak, tapınak) olduğunu gösterir. Bu adak Kybele heykelciklerinin dikkat çekici yanı ise Lidya/Arkaik değil de çok inandırıcı bir şekilde Grek estetik stilini ve ikonografyasını yansıtmasıdır. Büyük İskender'in Sardeslileri "azat" etmesinden iki nesil sonra başlayan bu İon/Grek kültür ve sanatını kabulleniş ve Sardes' in "hellenize" oluşu, Seleukoslar devrinde en olgun ve inandırıcı örneklerini vermiştir (Gallart-Marqués, 2019, 120-31).

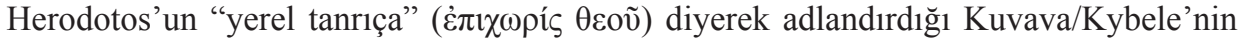
Arkaik ve Hellenistik Sardes'te diğer tapınak ve kutsal alanlarının nerede olduğunu bilmiyoruz. Herodotos'a göre MÖ 499 İonia isyanında Arkaik bir Kybele tapınağı yanmıştır fakat yeri bilinmemektedir (Herodotos, 5.102). Bir tapınak olmasa bile, kuzey Paktolos vadisindeki altın arıtma bölgesi, dört köşesi arkaik aslanlarla bezenmiş büyük bir Kybele sunağının gözlem ve koruması altındaydı. Bu sanayi alanı ve kutsal yerin 800-900 m güneyindeki büyük Artemis Kutsal Alanı öncelikle Artemis' in mekânı olsa da ilk baştan beri kentin ana tanrıçası Kuvava'nın da burada onurlandırdığı kuvvetli bir tezdir. Zaten bu iki doğa tanrıçası gerek nitelikleri gerek tapınma şekilleriyle birbirlerine benzeyen, aynı ikonografyayı kullanan, örtüşen, bütünleşen tanrıçalardır [Resim 1]. Ayrıca, Artemis'in geniş kutsal alanının başka kültlere de ev sahipliği yaptığına dair bazı veriler bulunmaktadır. MÖ 1. yüzyıla tarihlenen bir yazıta göre, Artemis kutsal alanına Zeus Polieos'u da kabul etmişti (uzun araştırmalara rağmen bölgede Zeus'a ait bir tapınak veya sunak bulunmamıştır fakat bu tabii ki olmadığ 1 anlamına gelmez) (Yegül, 2020a, 206-12 ve 206, n. 238; Ayrıca, Butler, 1922, 114, 124; Buckler \& Robinson 1932, 63-64, nos. 47- 48) Kent merkezinde MÖ 4. yüzy1l ortalarından kalma bir Kybele tapınağı (Metroon) olduğunu sinagogda devşirme malzeme olarak kulanılan 12 mermer bloğun incelenmesi sonucu öğrendik. Tapınak veya benzeri bir kült binasının antalarını (yapının yan duvarlarının uzantısı) oluşturan bu bloklardan dördünün üzerinde MÖ 213'e tarihlenen bir olaya atfen kral III. Antiokhos ve Kraliçe Laodike'nin Sardeslilere yazdığı mektuplar sergileniyordu (bkz., yukarıda). Bu blokların dışında, sinagog yapısında kullanılan Arkaik ve Lidya dönemi blokları, ve bazılarında Kybele/Artemis betimlemeleri 
bulunan mermer parçaların da belki bu Kybele kült merkezinin yakında bir yerde olabileceği tezini kuvvetlendirir.

\section{Roma Döneminde Sardes}

Sardes'in Roma döneminde kent gelişmesi açısından önceki dönemlere göre daha hacimli projelerin ve daha fazla mimari eserin yerini ve niteliğini bildiğimizi söyleyebiliriz. Yine de genel kent geometrisini ve planını detaylı bir şekilde bildiğimizi öne süremeyiz. Augustus ve İmparatorluk devri ile başlayan bu dönemde, daha önce bahsettiğimiz gibi kente bir 1zgara plan tasarımı uygulanmamıştır. Eski doğu-batı ana yolu, mermer döşeli ve sütunlu bir cadde şeklinde ve yer yer dükkânlarla geliştirerek (özellikle caddenin hamamgymnasion kompleksinin cephesinde) yerleşimi "yukarı kent," "aşağı kent” olarak ikiye ayırmaya devam etmiştir [Resim 2, 3]. Belki geç Hellenistik dönemden kalma ikinci bir yol, kuzey Paktolos'dan diyagonal şekilde uzanıp, sütunlu mermer cadde ile eski batı Lidya sur kapısının köşesinde birleşiyordu. Lidya suru ve sur kapısı çoktan yerle bir edildikten sonra, geç Roma döneminde burada Anadolu'da eşine çok rastlanan “zafer takı” tipinde, üç kemerli çok büyük bir "Anıtsal Kent Kapısı” ("Batı Kapısı” veya tetrapylon) yapılmıştı (Kapının 13 m açıklıklı orta kemeri Roma dünyasında bildiğimiz en büyük zafer takı kapı kemer açıklığıdır.) (Hanfmann, 1983, 141-48; Yegül, 1987, 46-61). [Resim 8] Bu önemli kent köşesi MS 2. yüzyılda gerçekleşen 'imparatorluk tipi' simetrik planlı çok büyük bir hamam-gymnasion kompleksi ile geliştirilmiş, belki Roma dönemi Sardes'inin en hareketli köşesi olmuştur. Plan tipi ve kullanılışıyla tonozlu bir Roma hamamını bir Yunan/Hellenistik gymnnasionu ile birleştiren Anadolu'ya özgü bu “hamam-gymnasion” yapısının Sardes'teki örneği, bu tipin hemen hemen en büyüklerindendir (batı yarısını hamam, doğu yarısını 100 sütunlu bir palaestra, spor alanı kaplar; girişi doğudaki yan caddeden, palaestraya doğrudur). Merkezî girişin karşısındaki iki katlı sütunlu imparatorluk onurlandırma alanına "Mermer Avlu" denilmektedir. (MS 3. yüzyılın başı) Bu alan 1964-1972 yılları arasında restore edilmiştir [Res. 9]. Bu hamam-gymnasion tipinin benzer örneklerine Ephesos, Aizanoi, Miletos, Alexandria Troas, Ankyra ve birçok başka kentte rastlıyoruz(Yegül, 1983, 148-61; Yegül, 1986).

Sardes'in Roma dönemi şehirciliği konusunda en önemli ve etkili olay kenti (ve batı Anadolu'nun diğer birçok kentini) yerle bir eden MS 17 yılındaki büyük depremdir. İmparator Tiberius felaketin ardından kent ile ilgilenmiş ve büyük para yardımlarının dışında, Senator Marcus Ateius'u yerinde incelemeler yapmak ve kentin yeniden yapılanmasını denetlemek için Sardes'e yollamıştır. Bu gelişmelerin mimarlık ve şehircilik açısından ne gibi sonuçlar yarattığını, kente Ateius'la beraber Roma'dan şehir plancılarının, mimarların, mühendislerin veya kadastro uzmanlarının gelip gelmediğini bilmiyoruz. Ancak, harap kentin mimari ve alt yapı sorunlarının teknik olarak incelendiği önemli bir gerçektir (Tacitus, Annales 2.47). Yazıtlardan öğrendiğimize göre bu dönemde başlayan kent su yolu ve su kemeri 
inşası imparator Claudius zamanında (MS 41-54) bitirilmiştir. Yine yazıtlardan bildiğimiz Sardes caddelerini süsleyen çeşmeler (ve bunlardan biri, kaidesi hamam-gymnasionun frigidariumunda bulunan, ağzından su akıtan birbirine dolanmış bronz yılanlı çeşmedir) bu Tiberius-Claudius ‘ana planının' parçaları olabilir miydi?

Sardes 'ana plan’ının (böyle bir "ana plan” olduğunu varsayıyoruz) belki başka bir uzantısı da kentin ilk “imparatorluk kültünü (neokoros) barındıran Vadi-B kült tapınağı ve bu tapınağın üzerinde yüksseldiği sütunlu Roma terasıdır [Resim 2, 10]. Bu muhteşem kompleks, stadionun 50-60 m batısında, Lidya 'sarayı' teraslarının altında, ovaya ve aşağı kente hâkim bir konumdadır. Kısa kuzey kenarının aks ortasına yerleşmiş anıtsal bir merdivenle çıkılan yapay teras yaklaşı 100x160 m yer kaplıyordu ve üç tarafi sütunlarla çevrili yüksek bir avlu-platform yaratıyordu. Ana hatlarıyla tipik Roma "tapınak kompleksi” planıyla Aizanoi Zeus tapınağı kompleksine benzer olmalıydı. Vadi-B kült tapınağı yaklaşık 23x39 m büyüklüğünde, önde sekiz Korinth düzeni sütunlu bir pseudodipteros idi. Tapınakta ele geçen çok miktarda mimari parça ve bezemeye bakarak (ve Sardes'in imparatorluk kült tarihini göz önünde bulundurarak) bu görkemli kompleksin MS 1. yüzyıl ortalarına veya üçüncü çeyreğine tarihlemesi yapılmaktadır (Yegül, 2020a, 217-20; Ratté, Howe \& Foss 1986, 4568). Bu tapınak ve terası büyük bir olasılıkla yeni büyütülmüş tiyatro ve stadionla beraber Sardes’teki Roma imparatorluk dönemi toplumsal hayatının çekirdeğini oluşturuyordu. Bir yazıtta kathados agoras ("agoradan aşağılara doğru”) diyerek betimlenen 'Roma agora'sı belki yokuş başında, Vadi-B tapınağına yakın yüksek bir yerdeydi (Buckler \& Robinson 1932, 3-40; Sardis VII.1, no. 17).

Kentin doğu-batı caddesinin kuzeyinde, ovanın düzlüğünde, iki büyük Roma yapısının harabeleri vardır. Bunlardan yola daha yakın olan "D Binası'nın” bol devşirme malzeme ile yapılmış, kaba taş blokların üzerinde yükselen kemerleri ve apsisi ile geç Roma (yaklaşık 4. yüzyıl) döneminden kalma bir kilise olduğu düşünülmektedir. Onun $350 \mathrm{~m}$ kadar kuzeybatısındaki " $\mathrm{C}$ Binası yine çift sıra taş payeleri, uzun tonozu ve bazilika planı ile büyük bir kamu binası olabilir. Kaliteli taş işçiliği ve devşirme malzemenin bulunmaması, MS 2.3. yüzyıl tarihini işaret etmektedir. Kentin doğu duvarlarının 100 m kadar dışında, yine ova düzlüğünde "CG Hamamı" olarak adlandırılan kalın duvarlı, tonozlu, apsisli büyük Roma hamamı (yaklaşık MS 2. yüzyıl ortaları) kısmen ortaya çıkarılmış ve yarı-simetrik planı ve havuzlu büyük mekânları ana hatlarıyla belirlenmiştir (Hanfmann \& Waldbaum 1975, 129-66) .

Sardes’te geç Roma/geç Antik dönemin başka bir görkemli ve önemli yapısı da Roma hamam-gymnasionunun palaestrasının güney kanadını oluşturan sinagogtur [Resim 8]. Belki palaestraya açılan bir spor salonu olan bu uzun, bazilika planlı, ahşap çatılı mekân kentin Yahudi toplumuna MS 5-6. yüzyıllarda verilerek bir sinagoga dönüştürülmüştür. 100 metreye yakın uzunluktaki ve bir ön avlu ile girilen ana salonu, şahane mozaikler ve duvarları opus sectile süslemeler ile kaplı bu önemli yapı Yakın Doğu’nun en büyük 
sinagogudur. Sardes'te Roma döneminde zengin ve politik açıdan güçlü ve bir ölçüde GrekHellen kültürünü benimsemiş bir Yahudi topluluğunun olduğunu gösterir. Bu sinagog Roma hamam-gymnasionunun "Mermer Avlu” salonu ile aynı yıllarda (1960-70) restore edilmiştir (Sardes Yayınları içinde yakında çıkacaktır).

Sardes’te birçok diğer antik kentte olduğu gibi anıtsal boyutlardaki kamusal ve dinî yapılar, küçük ve dayanıksız malzeme ile yapılmış meskenlerden daha iyi korunmuştur. Ayrıca, yamaçların heyelan ve depremde kayması, vadilerin dolması ile birçok zayıf yapılı ev grubu kaybolmuş veya derinlere gömülmüşlerdir. Ev gruplarının yamaçlar üzerine aralıklarla serpiştirilmiş olduğu düşünülebilir; özellikle akropolisin alçak kuzeybatı tepelerinde (HOB denilen bölgenin üstünde) böyle kademeli bazı yerleşim izleri bulunmuştur [Resim 8, 2]. Kaliteli malzeme ile yapılan ve iyi bir su ve drenaj sistemiyle donatılmış olan bu evlerin Ephesos’taki ünlü "Yamaç Evleri”ne benzeyen gruplar oluşturduklarını düşünebiliriz. Hellenistik ve Roma kentinin büyük teraslı yapıları arasında yayılan ve kademelerle yükselen evlerin kentsel topografya bütünlüğü içinde tablo gibi bir görüntü yarattıkları kuşkusuzdur. Kentin Batı Kapısı yakınlarında yer alan bir grup geç Roma ve Bizans dönemine ait ev, apsisli küçük salonları basit fakat güzel duvar resimleri ile dikkati çeker(Rautman, 2008, 147-58). Ayrıca, Anıtsal Batı Kapısı'nın 100 m kadar batısında (hamam-gymnasion ile mermer caddenin hemen güneyinde) yer alan 'domus' tipi büyük, lüks bir ev (HOB olarak adlandırılmıştır) Roma döneminde de kent surları dışında yerleşme olduğunu gösterir [Resim 8]. Belki, Roma dönemini konuşurken, "kent dışı" tanımlamasını yapmak biraz yanlış olabilir, çünkü Sardes’in (ve diğer Anadolu kentlerinin) en zengin ve en güvenli dönemi “'Roma Barışı'nın hâkim olduğu İmparatorluk dönemidir ve bu dönemde kentler, Roma'da da olduğu gibi, eski surlarını yıkmışlar, ve sur-dışı yerleşimlerini geliştirmişlerdir. Ancak, MS 4-5. yüzyıllarla birlikte çeşitli dış tehlikelere karşı bugün büyük kısmı görülebilen ve genelde eski Lidya surlarının güzergâhını izleyen, moloz taşlı "Bizans" surlarını inşa etmişlerdir. HOB evi geç Roma döneminde terkedilmiş, bölge işlikler ve atölyeler olarak sur dışı yaşamını sürdürmüştür. Bu dönemde Paktolos vadisindeki basit ev grupları ve atölyeler tekrar canlanmış, hatta bazı meskenlerin küçük özel hamamları bile olduğu görülmüştür. Bu yerleşim grubunun önemi (kent dışı "mahalle" diyebiliriz) MS 4. yüzyıla tarihlenebilen bazilika planlı büyük bir kilise ("EA" kilisesi) ile vurgulanmıştır.

\section{Roma Döneminde Artemis Tapınağı}

Mimari ve kentsel gelişmeler içinde Roma döneminin Sardes'e en önemli ve kalıcı katkısı kuşkusuz Seleukoslar döneminde başlanarak, yalnızca cella kısmı tamamlanan Artemis tapınağındaki yeni yapılanmalardır. Seleukosların yönettikleri bazı Batı Anadolu kentlerinde "politik bir gösteri" olarak da tanımlayabileceğimiz büyük yapı etkinliklerinin, bir başkent olarak önemsedikleri Sardes’teki uygulanışı, kentin Artemis kutsal alanının görkemli bir tapınakla onurlandırılmasıyla olmuştur [Resim 1]. Bu ilk Artemis tapınağının, 
Sardes'e gelmeden çok önce, tanrıça Artemis'e ve diğer çeşitli kültlere bağışlarda bulunan, önce I. Seleukos'un sonra I. Antiokhos'un kraliçesi Stratonike olduğunu öne sürmüştük (bkz., yukarıda). Resmî mekânları olarak Sardes'i seçen bu kuvvetli kraliyet çiftinin o dönem "tapınaksız" olan Artemis kutsal alanını bir tapınakla taçlandırmış olmaları akla yakındır. Bu çok uzun cellanın (1:2.9 oranında, Bitirilmesi halinde İonia'nin diğer ünlü Arkaik tapınakları gibi bir dipteros olarak tasarlandığını sanıyoruz.) Üç yüzyıl tek bir cella olarak hizmet veren bu ilk tapınağın bitirilmesi ve yeniden inşasının sebebi ise imparator Hadrianus ve Sabina'nın MS 123/124'te Sardes'i resmi ziyaretleridir [Resim 11]. Bu ziyaretle ilgili Sardes'e "ikinci neokoros" ayrıcalığı (ve belki maddi yardım) bahşeden Hadrianus, imparatorluk kültü için ayrı bir tapınak yapmak yerine, kültü hazırda olan Artemis tapınağına taşımış, yeni “tanrıları” Artemis’e ortak etmiştir. Bu ortaklığa pratik ve ekonomik çıkarlar gözetilerek Sardes kenti idarecileri kendileri karar vermiş olabilirler. Cellanın etrafında inşası başlanan sütun sırası (peripteros) dışında, yeniden yapılanma şöyle olmuştur: cella ince bir duvarla bölünüp, iki ayrı cella yaratılmıştır [Resim 12A, 13, 11]. Artemis nekropolise (ve büyük sunağına) bakan batı cellasında kalmıştır; yeni imparatorluk kültü imparator ailelerinin dev heykelleri ile doğu cellasına taşınmıştır. Hadrianus ve Sabina ile başlayan kült zamanla bütün Antoninuslar hanedanını da içine almıştır. Dev mermer heykel başlarından 7-8 adet bulunmuştur (Antoninus Pius, Yaşlı Faustina, Marcus Aurelius, Lucilla, Sabina? ve Commodus). Cella'nın etrafı sütunlarla çevrelenip, kısa cephelerinde sekiz ion düzeni sütun bulunan bir pseudodipteros yaratılmıştır [Resim 13, 12A]. Yeni yapı belki de klasik dünyanin en büyük pseudodipterosudur (97.60x44.60 m). İlginçtir ki imparatorluk kültünün cephesi olan doğu tarafi bütün sütunlarıyla bitirilmiş olmasına rağmen, Artemis'in tarafı olan batı (tapınağın orijinal ‘ön’ tarafının) sütunlarının temellerinin yapımına bile başlanmamıştır. Yani Hadrianus ve imparator ailesi, kentin Artemis'ini destekleyerek ön sırayı almışlardır. $\mathrm{Bu}$ durum Sardes'in ve Anadolu'nun diğer kentlerinin, imparatorluğun toleranslı idaresi altında her ne kadar "özgür” oldukları sanılıyorsa da aslında hepsinin Roma'nın kesintisiz kontrolünde olduklarının politik gösterisidir (Butler, 1925; Yegül, 2020a; Yegül, 2019, 13238; Yegül, 2020b; Yegül, 2010b, 363-88).

Cellası eşit olmayan koridorlar (pteroma) ile çevrelenen (yanlarda iki, on ve arkada üç sıra sütun açıklığı vardır) ve ön ve arkalarda (pronaos) Yunan tapınak mimarisinde eşine rastlanmayan, altı sütunun çevrelediği, belki göğe açık, "pronaos avluları" ile Sardes pseudodipterosu Anadolulu Mimar Hermogenes' in MÖ 3. yüzyılın ikinci yarısında yarattığ standart pseudodipteros tasarımı ile ilgisi olmayan bir mimari ortaya koyar [Resim 14]. Bu standart psesudodipterosun en önde gelen ve ilk örneği mimarın Menderes Magnesia'sındaki Artemis tapınağıdır (veya onun Hellenistik dönem takipçilerinden Alabanda'daki Apollon Tapınağı ve Roma döneminden Ankyra'daki Augustus ve Aizanoi'deki Zeus tapınaklarıdır: [Resim 12B, C, D]. Sardes Artemis tapınağı, bu tapınaklardan sadece plan ve şekil olarak değil, kütle, mekân ve ışık kullanımındaki dramatik ve yaratıcı bütünlüğü ile de farklıdır. 
Sardes'in sıradışı pseudodipterosu tekrarlanmayan (ve bitirilemeyen) bir mimari deneyim olarak kalmıştır (Yegül, 2020a, 225-55, özellikle 247-52).

\section{Sonuç}

Tarih boyunca ve değişik idareler altında, Sardes’i yüzyıllar boyu, Asya/Anadolu'nun ortak kültür ve ortak-lisanlı (Anadolu koinesi) bütününün diğer kentleri arasında değişik ve benzersiz yapan nedir? Sardes'i antik Anadolu kentleri içinde hangi özelliği ile adlandırırız ve hatırlarız? Hangi özelliği ile Seleukos krallarının, kraliçelerinin, Pers satraplarının ve derebeylerinin ve Roma imparatorlarının nezdinde kabul ve sevgi görmüştür? Bu soruların cevabı, kentin muhteşem surları, mermer caddeleri, yılan başlı çeşmeleri, akropolisinin dik yamaçlarından uçar gibi yükselen terasları ve sarayları, hatta Artemis'i ve Kybele'si için yapılan görkemli tapınaklarının somut yapılarında değil, onların canlandırdığı soyut dünyada ve Sardes'in insanlarının düşlerinde ve düşüncelerindedir. Nesiller boyu hayallerdeki “Altın Sardes" Lidya imparatorluğunun ve Kral Kroisos'un başkenti olarak yarattığı tarihî ve mitolojik çekiciliğini hiç kaybetmemiştir. Defalarca Sardes'in ve Sardeslinin romantik geçmişi şiir ve şarkılarda yaşamış ve “kentin çiçeklerle kaplı Tmolos’un gölgesindeki yeri tüm Lidya'nın ve Asya'nın metropolisi” olarak gerçekte olmasa bile hayal ve hatıralarda kalmıştır(Anthologia Graeca, IX, 645; Foss, 1976, 109, no.9; Yegül, 1987, 59-60; Yegül, 2020a, 206-07, n. 243, 244).

\footnotetext{
Hakem Değerlendirmesi: Dış bağımsız.

Çıkar Çatışması: Yazar çıkar çatışması bildirmemiştir.

Finansal Destek: Yazar bu çalışma için finansal destek almadığını beyan etmiştir.

Peer-review: Externally peer-reviewed.

Conflict of Interest: The author has no conflict of interest to declare.

Grant Support: The author declared that this study has received no financial support.
}

\section{Kaynakça/References}

Berlin, A.M. (2019). Archaeology of a Changing City. Spear-Won Land, 50-67.

Berlin, A.M. \& Kosmin, P. (Eds.). (2019). Spear-Won Land. Sardis from the King's Peace to the Peace of Apamea. Madison, Wisconsin.

Buckler, W. H. \& Robinson, D. M. (1932). Sardis. Greek and Latin Inscriptions, VII (Publications of the American Society for the Excavation of Sardis), Leyden.

Butler, H. C. (1922). Sardis. The Excavations 1910-1914, I.1 (Publications of The American Society for the Excavation of of Sardis), Leyden.

Butler, H. C. (1925). Sardis. The Temple of Artemis, II.1 (Publications of the American Society fort he Excavation of of Sardis), Leyden.

Cahill, N. D. (2019a). Inside Out: Sardis in the Achaemenid and Lysimachean Periods. Spear-Won Land, 11-36. 
Cahill, N. D. (2019b) Spotlight: The Metroon at Sardis. Spear-Won Land, 91-96.

Foss, Clive. (1976). Byzantine and Turkish Sardis (Archaeological Exploration of Sardis, Monographs 4), Cambridge, Mass.

Gallart-Marqués, F. (2019). A Clay Cybele in the City Center. Spear-Won Land, 120-31.

Greenewalt, Jr. C. H. (2010). Lidya Tanrıları. Lidyalilar ve Dünyalart - The Lydians and Their World, N. D. Cahill. (Ed. ). İstanbul, 233-46.

Hanfmann, George M. A. (1983). Sardis from Prehistoric to Roman Times, 1958-1975. Cambridge. Mass.

Hanfmann, George M. A. \& J. Waldbaum. (1975). A Survey of Sardis and the Major Monuments Outside the City Walls (Archaeological Exploration of Sardis, Report 1), Cambridge, Mass.

Kosmin, P. J. (2019). Remaking a City: Sardis in the Long Third Century. Spear-Won Land, 75-90.

Mierse, W. E. (1983). The Persian Period. Sardis from Prehistoric to Roman Times, 100-108.

Pedley, J. G. (1972). Ancient Literary Sources on Sardis (Archaeological Exploration of Sardis, Monograph 2), Cambridge, Mass.

Ratté, C. (2008). Reflections on the Urban Development of Hellenistic Sardis. N. D. Cahill (Ed.), Love for Lydia: A Sardis Anniversary Volume Presented to Crawford H. Greenewalt, Jr., (Archaeological Exploration of Sardis, Report 4), Cambridge, Mass., 125-33.

Ratté, C. (2011). Lydian Architecture: Ashlar Masonry Structures at Sardis (Archaeological Exploration of Sardis, Report 5), Cambridge, Mass.

Ratté, C. T.N. Howe \& C. Foss, (1986). An Early Imperial Pseudodipteros Temple at Sardis. AJA 90, 45-68.

Rautman, M. (2008). The Aura of Affluence. Domestic Scenery in Late Roman Sardis. Love for Lydia, 14758.

Stinson, P. (2019). The Hellenistic City Plan: Looking Forward, Looking Back. Spear-Won Land, 139-44.

Yegül, F.K. (1983). The Bath-Gymnasium Complex. Sardis from Prehistoric to Roman Times, 148-61.

Yegül, F.K. (1986). Ther Bath-Gymnasium Complex at Sardis (Archaeological Exploration of Sardis, Report 3), Cambridge, Mass.

Yegül, F. K. (1987). Roman Architecture at Sardis. E. Guralnick (Ed.), Sardis. Twenty-Sevcen Years of Discovery, Chicago, 46-61.

Yegül, F. K. (2010a). From the Lofty Halls of Academia to the Dusty Hills of Anatolia: Howard Crosby Butler and the First Sardis Expedition through Peace and War, 1909-1926. S. Redford \& N. Ergin (Eds.), Perceptions of the Past in the Turkish Republic: Classical and Byzantine Periods, (Ancient Near Eastern Studies, Suppl. 31), Leuven, 57-100.

Yegül, F. K. (2010b). Sardeis Artemis Tapinagi. N. D. Cahill (Ed.), Lidyalilar ve Dunyalari - The Lydians and Their World, Istanbul, 363-88.

Yegül, F. K. (2013). Yağmalanan Sardes ve Türk Arkeolojisinin Geçmişle İlk Hesaplaşması. G. Kökdemir (Ed.), Orhan Bingöl'e 67. Yaş Armă̆anı, Ankara, 711-726.

Yegül, F K. (2019). The Temple of Artemis. Spear-Won Land, 132-38.

Yegül, F. K. (2020a). The Temple of Artemis at Sardis, 2 vols. (Archaeological Exploration of Sardis, Report 7), Cambridge, Mass.

Yegül, F. K. (2020b). Artemis Tapınağı ve Altın Sardes’in Kraliçeleri. Seleucia 10, 9-33. 


\section{Figürler}

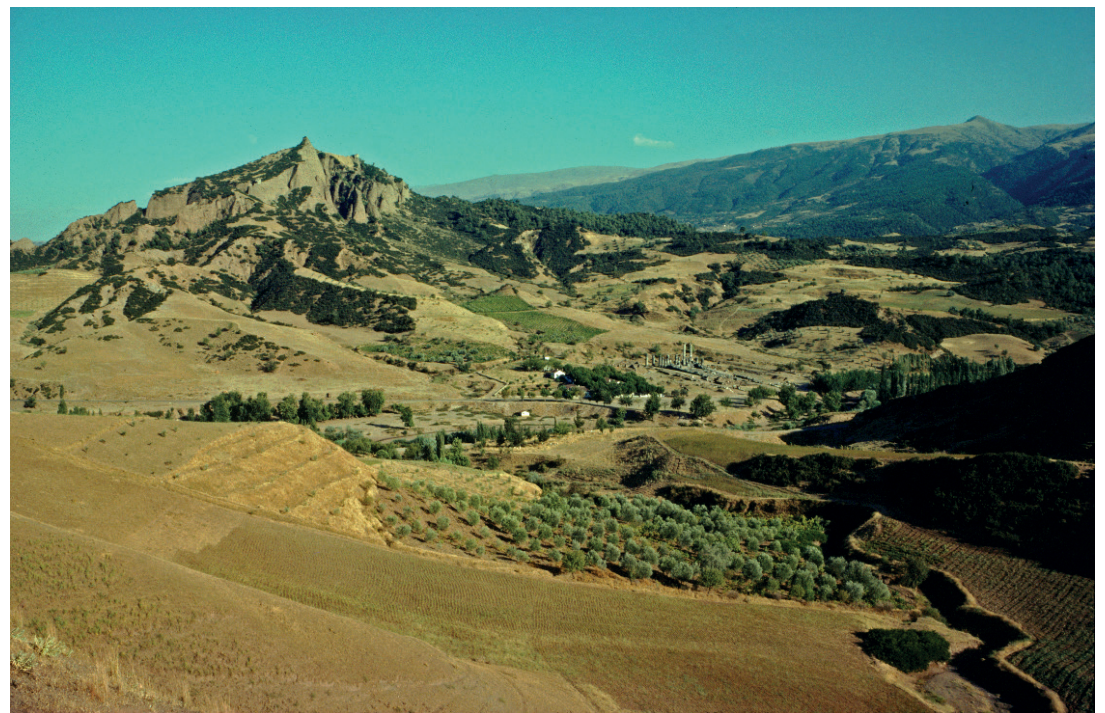

Figure 1. Artemis tapınağı, akropolis, Paktolos vadisi, ve arkada Tmolos (Bozdağlar) dağları, genel görünüm doğuya bakış. (F. K. Yegül).

\section{SARDIS KENT PLANI}

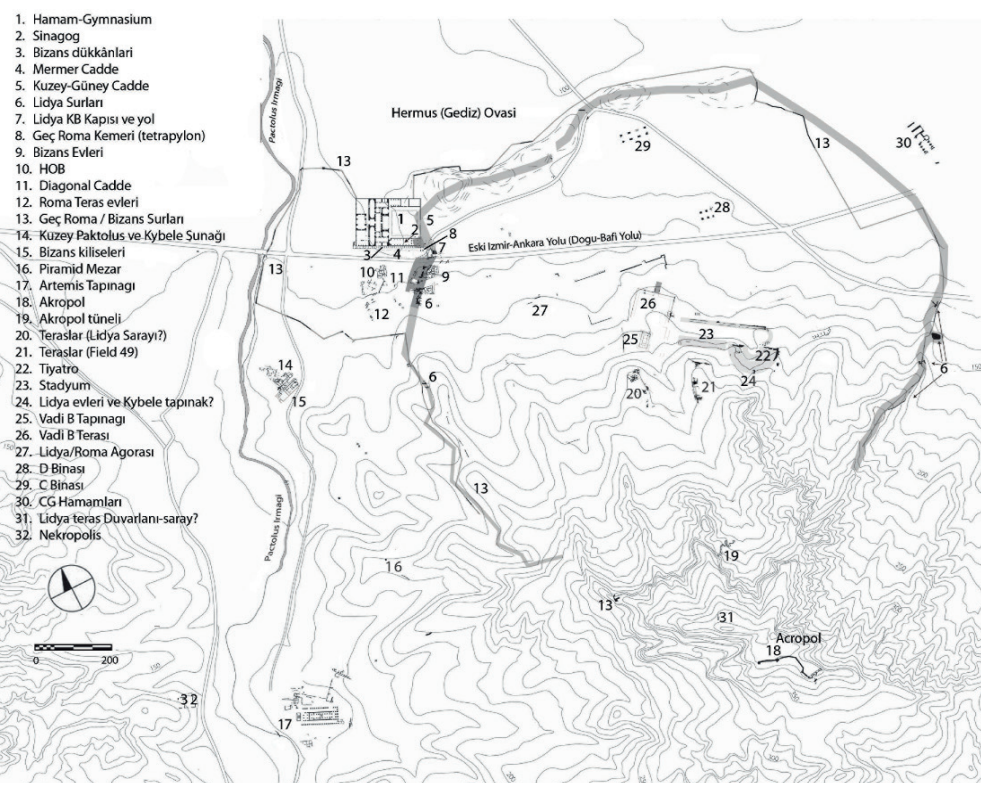

Figure 2. Sardes Kent Planı (Sardes Arkeolojik Kazıları). 


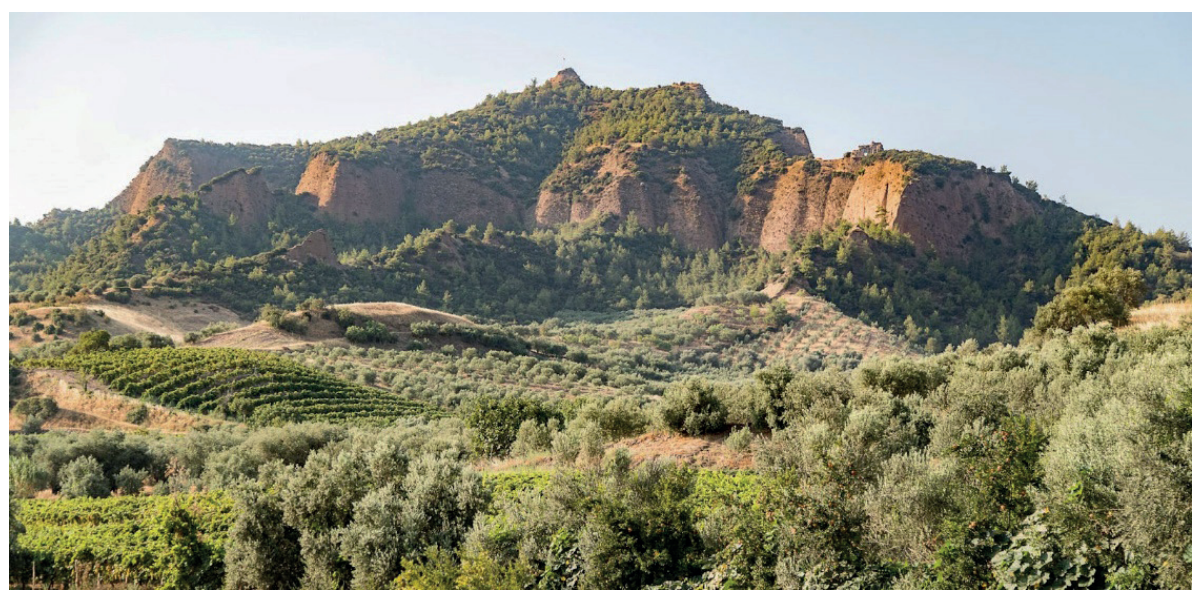

Figure 3. Sardis akropolisi kuzey tarafının genel görünümü, güneye bakış. (F. K. Yegül).

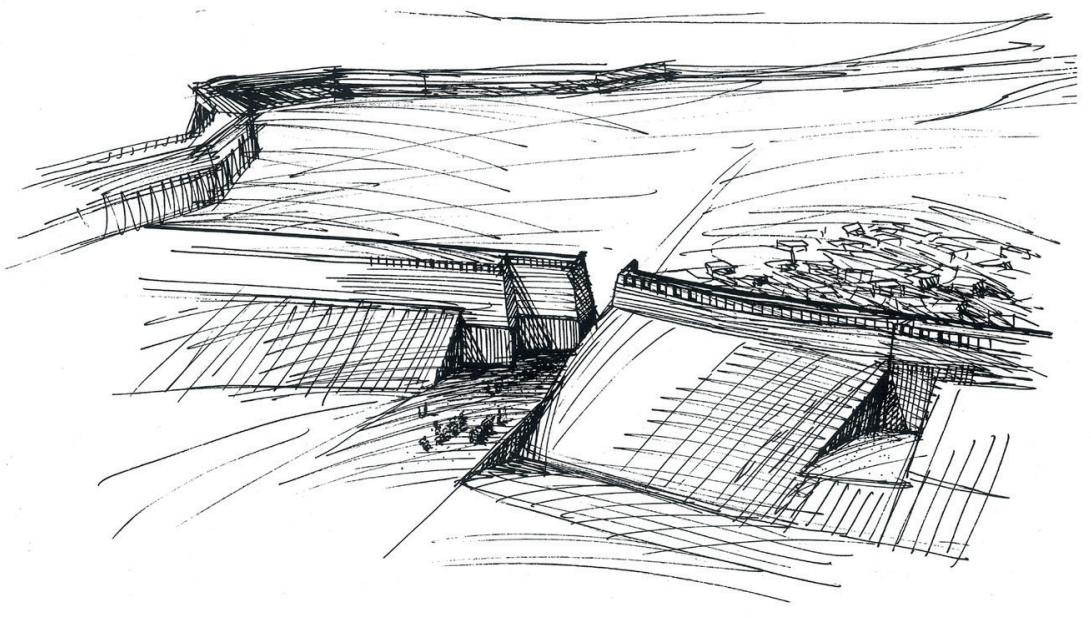

Figure 4. Sardes Lidya surlarının restorasyon eskiz çalışması, batı sur kapısı, doğuya, kentin içine doğru bakış [Sardes Arkeolojik Kazıları, P. Stinson). 


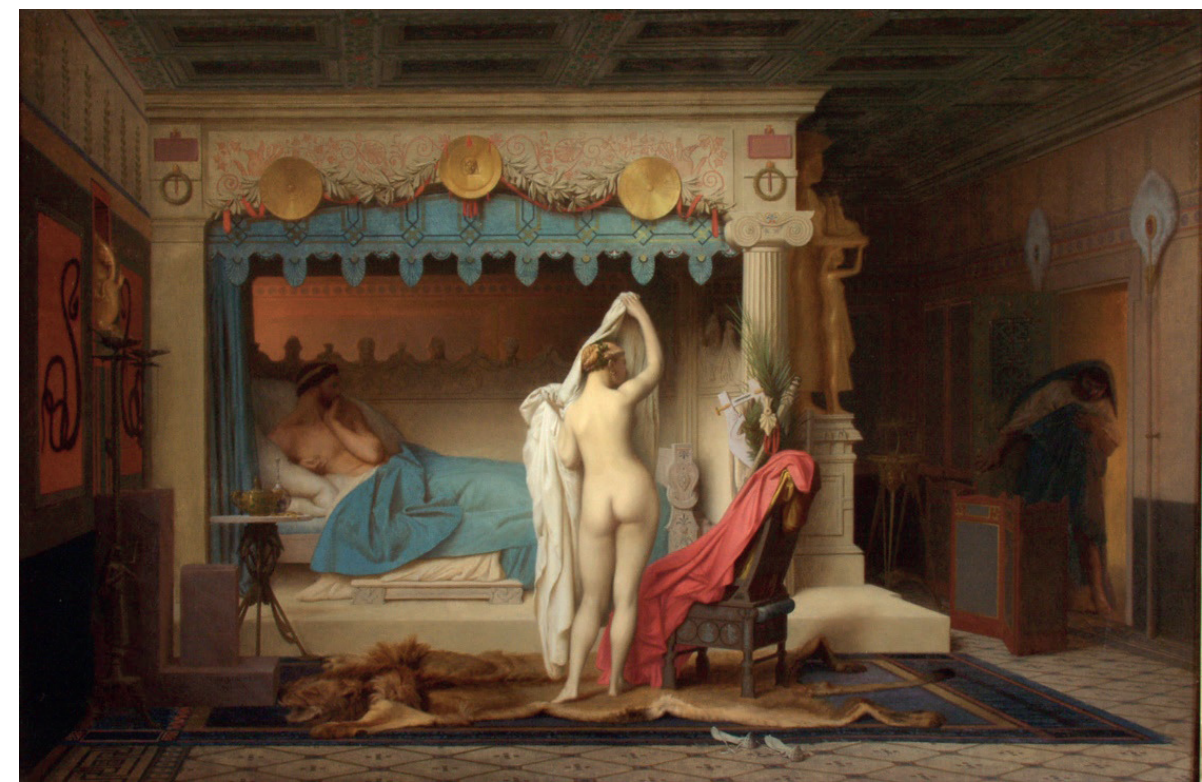

Figure 5. J-L. Gerome, Gyges ve Kral Kandaules’in Kraliçesi, 1859. Museum of Art, Le Ponce, Puerto Rico (Wikimedia Commons).

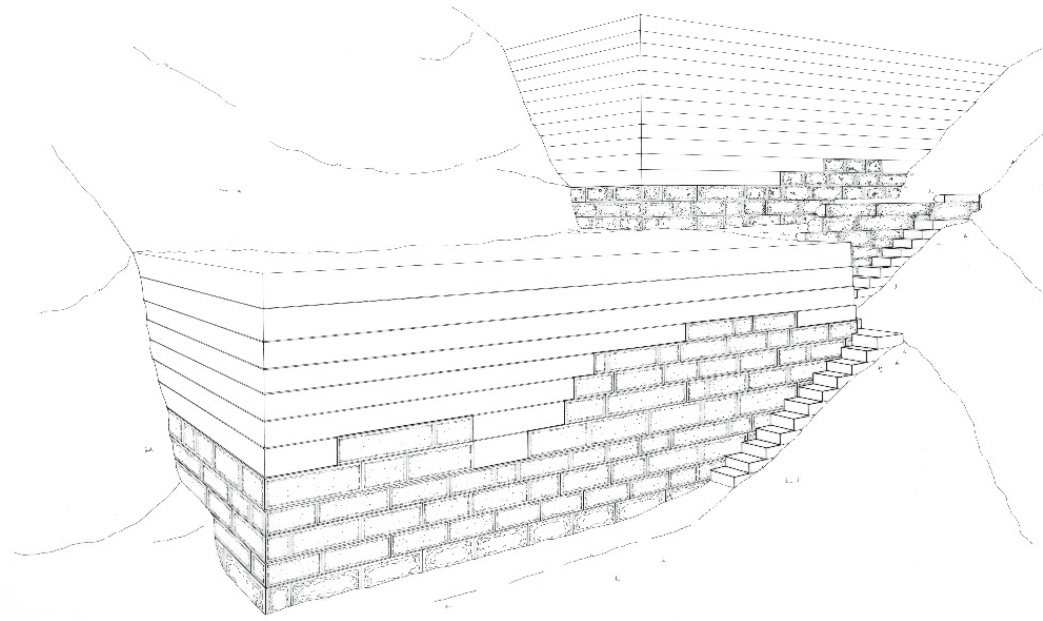

Figure 6. Akropolisin kuzeyindeki (zirveye yakın) Lidya teras duvarları ve merdivenleri, perspektif (Sardes Arkeolojik Kazilari). 


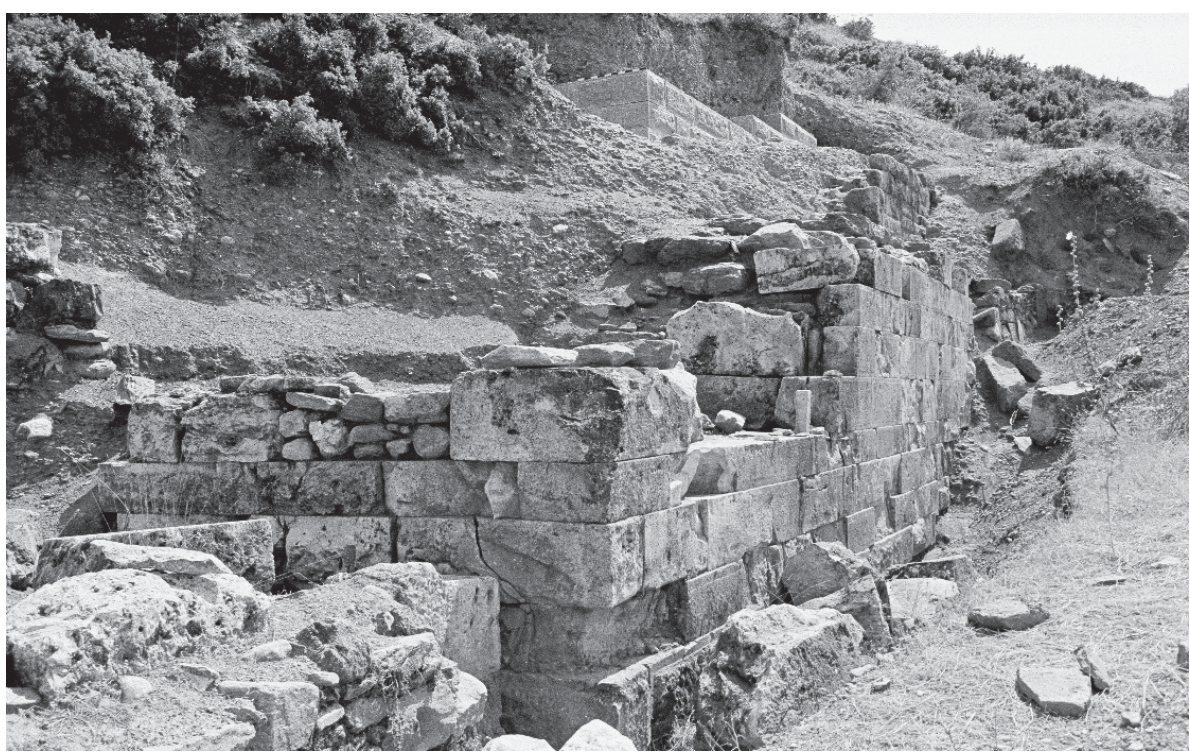

Figure 7. Akropolisin kuzeyindeki (zirveye yakın) Lidya teras duvarları, aşağıdan yukarıya görünüş (Sardes Arkeolojik Kazıları).

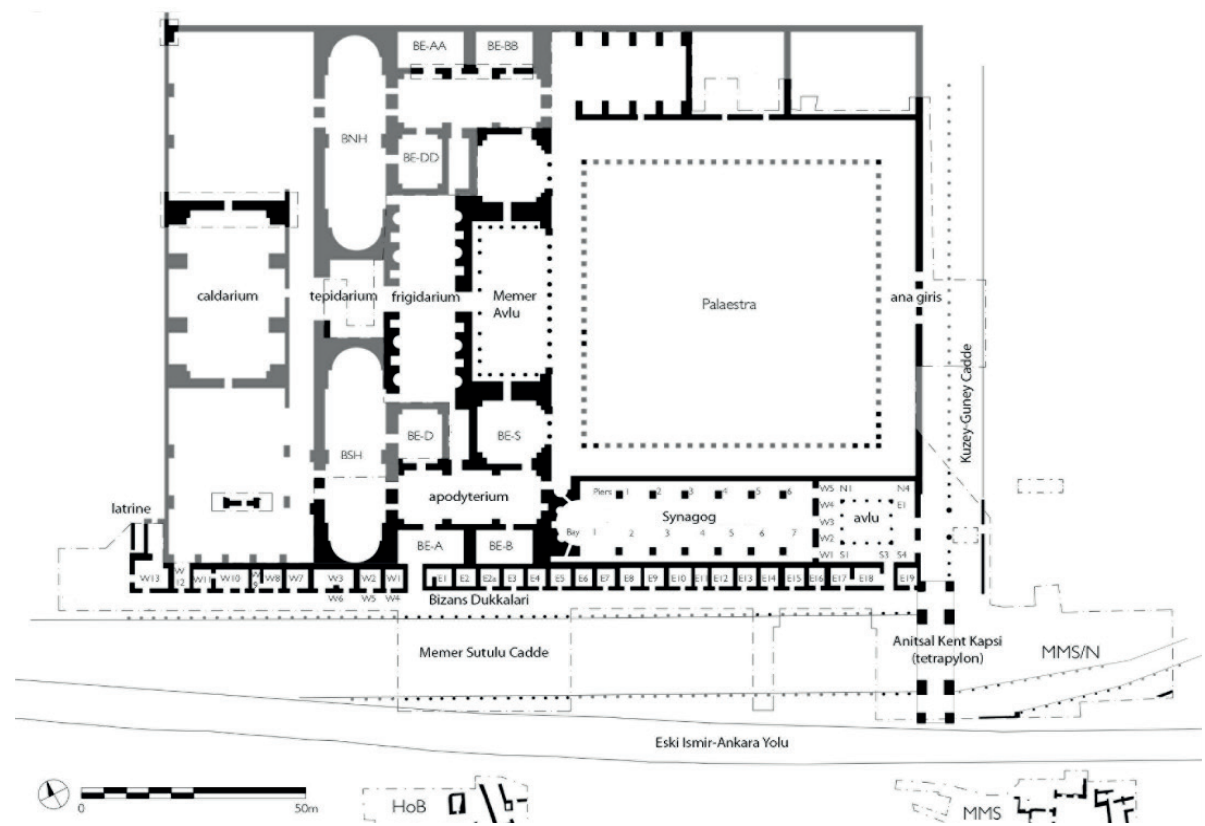

Figure 8. Sardes Roma Hamam1-Gymnasion, plan (sinanog, sütunlu mermer cadde ve anıtsal kent kapısı) (F.K.Yegül ve Sardes Arkeolojik Kazılar). 


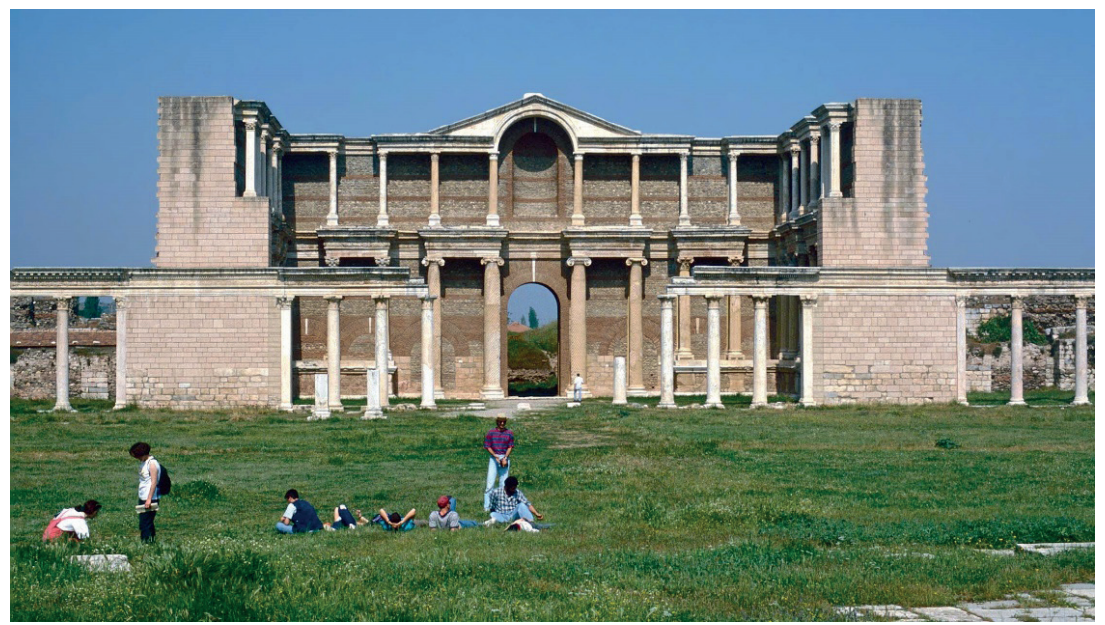

Figure 9. 'Mermer Avlu', Roma Hamamı-Gymnasion'u, batı'ya bakış (F. K.Yegül).

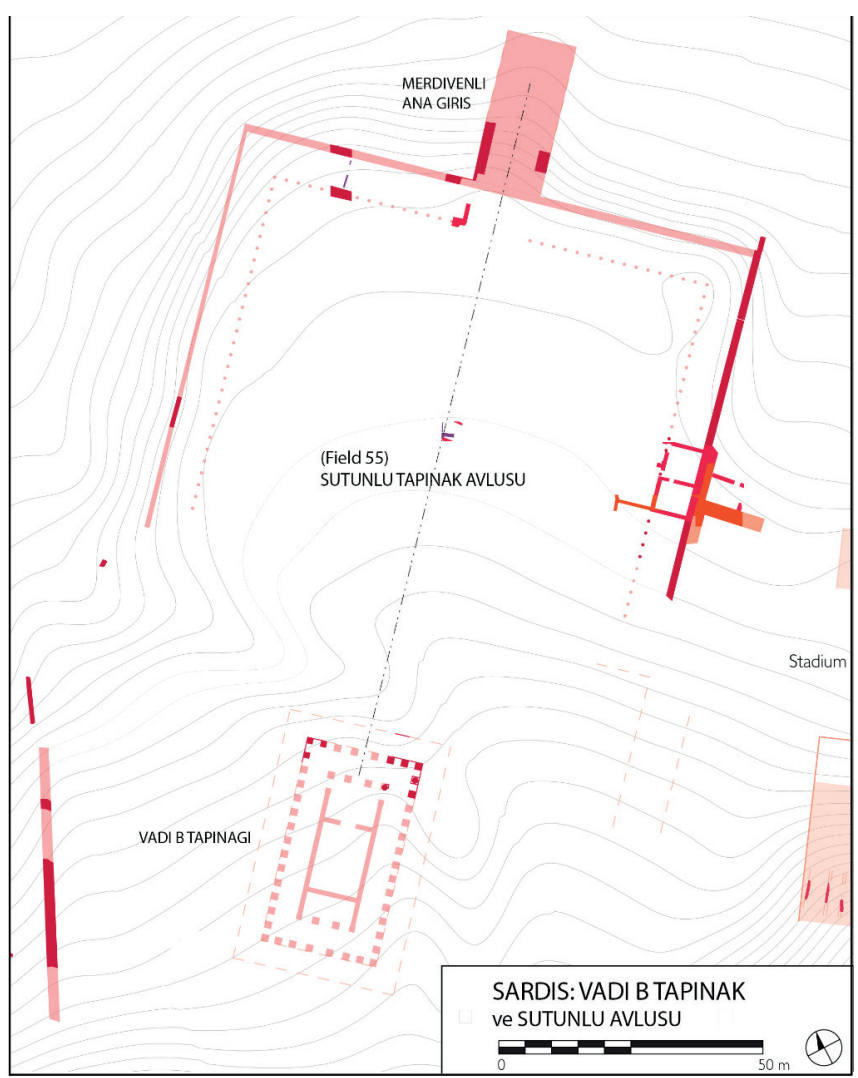

Figure 10. 'Vadi B Tapınağı ve Sütunlu Avlusu, plan (Sardes Arkeolojik Kazıları). 


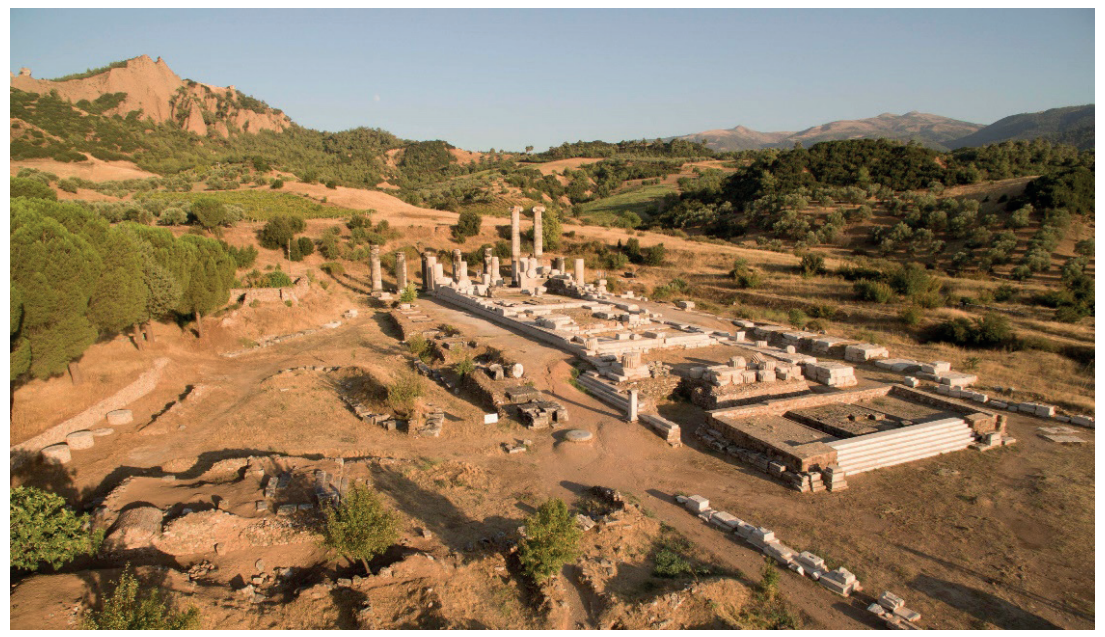

Figure 11. Artemis Tapınağı genel görünüm, önde büyük sunak, arkada Sardes akropolisi, güneydoğu'ya bakış (Sardes Arkeolojik Kazıları).
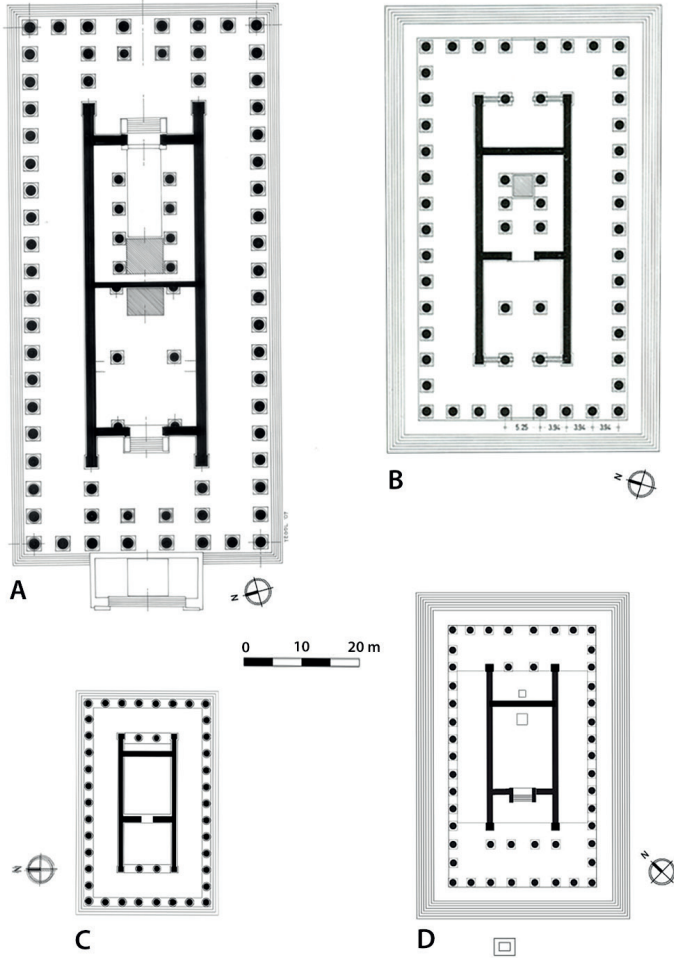

Figure 12. 4 Anadolu pseudodipterosu planları karşılaştırması: a) Sardes, Artemis Tapınağı; b) Magnesia, Artemis Tapınağı: c) Alabanda, Apollo Tapınağı; d) Ankara, Augustus Tapınağ1

(F. K. Yegül). 


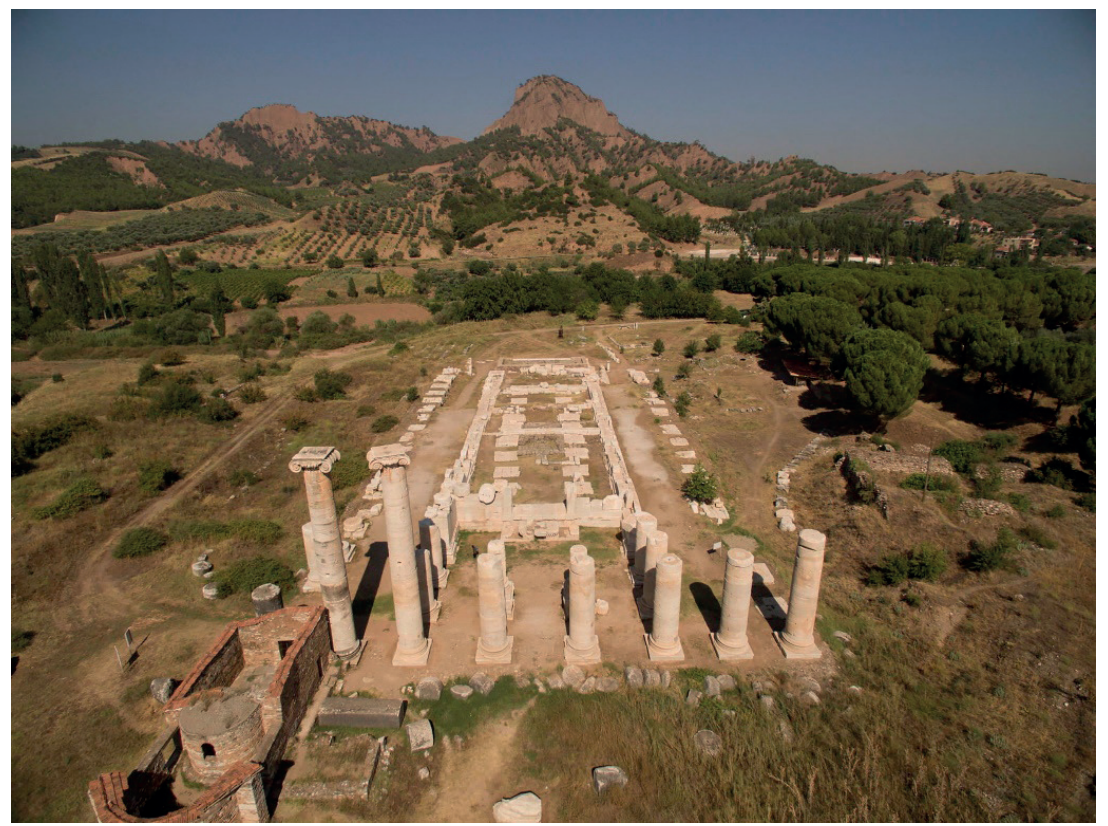

Figure 13. Artemis Tapınăğ, genel görünüş, doğu cephesi, batıya (Nekropolise) bakış (Sardes Arkeolojik Kazıları).

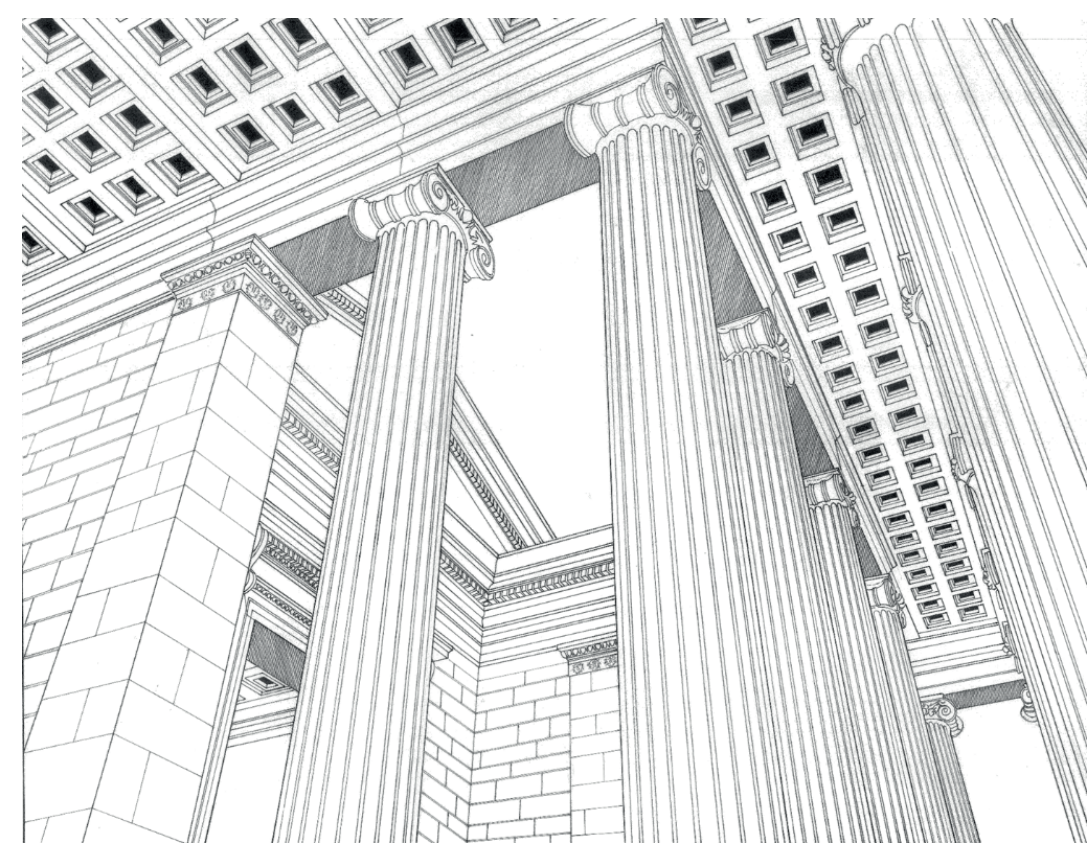

Figure 14.Artemis Tapınağı doğu pronaos avlusu, restorasyonu (F. K. Yegül). 